\title{
Testimonios
}

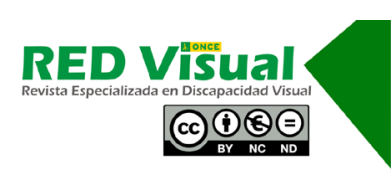

Recepción: 04-03-2021 Aceptación: 24-03-2021

\section{Jubilarse en pandemia}

\author{
M. J. Vidal Castro
}

Me jubilé el 13 de diciembre de 2019, día de Santa Lucía, después de años de trabajo como auxiliar de enfermería en la planta de medicina interna de un hospital público.

Acostumbrada como estaba a convivir con virus, hongos, bacterias, bacilos y toda suerte de microorganismos patógenos que afectan a los pacientes, no podía entender que, al poco tiempo de haberme jubilado, el mundo se pusiera patas arriba por mor de un virus y que tuviéramos que utilizar una mascarilla permanentemente, complemento demasiado incomodo que conocía muy bien por tener que usarla en mi trabajo en los aislamientos y que, además de hacerme sudar, me empañaba las gafas, lo cual, añadido a mi baja visión, dificultaba mi atención al paciente.

Las actividades culturales que tanto ansiaba al jubilarme, y que antes por los turnos del trabajo se me hacía difícil realizar, tuvieron que ser a través de las distintas plataformas digitales a las que no estaba acostumbrada, como es habitual para las personas de mi edad y que, además, hay que añadir la dificultad de no ver.

Creo que el teatro me salvo de caer en una depresión, actividad a la que llevo vinculada 25 años en el grupo Valacar de La Coruña, perteneciente a la ONCE, que, desde el primer momento del confinamiento, pudimos continuar ensayando (cada uno desde su casa) y, además de seguir aprendiendo, hemos llegado a montar una obra completa cuyo trabajo está reflejado ya en vídeo, cosa que nunca hubiera podido imaginar. Esto me enorgullece doblemente dada la dificultad que esto supuso para nosotros, acostumbrados como estábamos a la presencia del público. 
Espero que esta situación acabe cuanto antes y que podamos mostrar nuestro pequeño gran arte como se merece.

María José Vidal Castro

Vidal, M. J. (2021). Jubilarse en pandemia. RED Visual: Revista Especializada en Discapacidad Visual, 77, 343 344. https://doi.org/10.53094/FFED3103. 